\title{
The physicochemical characteristics of whey dangke fermentation powder at various levels of carrageenan and drying time
}

\author{
Wahniyathi Hatta $^{1 *}$, Farida Nur Yuliati ${ }^{1)}$, Endah Murpi Ningrum ${ }^{1)}$ \\ ${ }^{1)}$ Department of Animal Production, Animal Husbandry, Hasanuddin University, \\ Makassar, Indonesia 90243
}

Submitted: 21 October 2019, Accepted: 22 November 2019

\begin{abstract}
Whey dangke fermentation producing lactic acid as a food additive can overcome environmental pollution caused by whey dangke; however, its high water content causes a short shelflife product and makes distribution difficult. Drying fermented products requires additional ingredients to overcome stickiness issue in the dryer. This research aimed to examine the use of carrageenan as drying aids at 4, 6, 8, and $10 \%$ levels and drying time of 23, 24, and 25 hours in the production of fermented whey powder in drying oven. The quality parameters of the fermented whey dangke powder included yield, water content, solubility, and protein and lactose contents. The results showed that the fermented whey dangke powder had a yield of 33.15-49.20\%; water content of 2.30-9.07\%; solubility of 94.0-99.0\%; protein content of 9,70-13,92\%; and lactose content of 7.92-15.58\%. Carrageenan level has a very significant effect $(\mathrm{P}<0.01)$ on yield, water content, and lactose content, and it also has a significant effect $(\mathrm{P}<0.05)$ on protein content, while drying time has a significant effect $(\mathrm{P}<0.05)$ on lactose content. The use of carrageenan at $8 \%$ level and 24-hour drying time is the most optimal treatment to produce the best physicochemical characteristics of fermented whey dangke powder.
\end{abstract}

Keywords: whey; dangke; fermentation; drying; carrageenan.

*Corresponding Author: wahnihatta@yahoo.com 


\section{INTRODUCTION}

Whey is commonly known as a yellowish green clear liquid obtained from filtering the curd after the casein clumping process in cheese production. It is one of the main issues in the milk processing industry because of its high production volume and high organic matter content; in addition, it has a biochemical oxygen demand (BOD) value of around $30-50 \mathrm{~g} / \mathrm{L}$ and chemical oxygen demand (COD) value of around 60$80 \mathrm{~g} / \mathrm{L}$. The high values of whey BOD and COD are mainly due to the lactose component (Domingues et al., 1999), and it can be used as a carbon source in the fermentation process as it contains lactose and various other nutrients that are essential for the growth of microorganisms.

Similar to other cheese processing businesses, the dangke industry in Enrekang district also produces large amounts of whey and have not been utilized in which most of this is discharged into rivers causing pollution problems for the environment. The number of dangke businesses in 2004 was 117 and increased in 2011 reaching up to 396 businesses (Disnakin, 2012). In general, every 1 kilogram of cheese produced will obtain around 9 liters of whey. If it is assumed that the dangke processing business in Enrekang produces at least $1 \mathrm{~kg}$ of dangke every day, the whey production can reach up to $3,564 \mathrm{~L} /$ day. Whey dangke fermentation to produce lactic acid is an effective process to reduce the environmental problem of pollution, and at the same time produce products with economic values. Whey dangke fermentation in liquid raises several problems, including: storage requires freezer, short shelf-life due to high water content allowing mold to grow. Besides, product quality is unstable, distribution requires special packaging and handling, and its application as a food additive can affect the quality of organoleptic products as it must be used in large quantities. The processing of whey dangke fermentation from liquid to powder is expected to increase its shelf-life, stability of product quality, ease of packaging and handling, and its application in food in small quantities.

Drying materials that have high levels of sugar and organic acids, like whey dangke fermentation, will encounter several obstacles such as stickiness in the dryer, agglomeration, and clumping which cause operational problems and low yield (Kha et al., 2010). This condition is caused by the presence of low molecular weights of sugar and acid having low glass transition temperature (Jittanit et al., 2010). To overcome the stickiness problem, high molecular weight additives can be added. Drying aids commonly used include various types of polysaccharides and proteins, including maltodextrin, starch, Arabic gum, and carrageenan (Fernandes et al., 2014). Krishnaiah et al. (2012) have reported the use of $\kappa$-carrageenan and maltodextrin as binding agents in the encapsulation process of Morinda citrifolia L. extract with a spray dryer. The effect of using a combination of $\kappa$-carrageenan $(\kappa \mathrm{C})$ and sodium carboxymethyl cellulose $(\mathrm{NaCMC})$ as a coating agent on antioxidant activity and physicochemical characteristics of spraydried Clinacanthus leaf powder was reported by Karim et al. (2017). The use of carrageenan as drying aids in drying fermented products has not been widely reported. This research aimed to assess the usage levels of carrageenan as drying aids and determine the best drying time in producing fermented whey dangke powder with a drying oven in accordance with the most optimum physicochemical characteristics of fermented whey dangke powder.

\section{MATERIALS AND METHODS Materials}

The samples of whey dangke were obtained from a dangke producer in Makassar, South Sulawesi, and were stored at $4^{\circ} \mathrm{C}$ before usage. The lactic acid bacterial 
culture used was Lactobacillus casei obtained from Pusat Antar Universitas (PAU) Gadjah Mada University, Yogyakarta.

\section{Preparation of Starter Culture}

Bacterial culture from NA media to be tilted was taken by one ose, then inoculated into $10 \mathrm{ml}$ of MRS broth media (Merck), and incubated at $37^{\circ} \mathrm{C}$ for 24 hours. Afterwards, $5 \mathrm{~mL}$ of inoculum was taken and grown in $100 \mathrm{~mL}$ of MRS broth media sterilized by autoclave at $121^{\circ} \mathrm{C}$ for 10 minutes. Subsequently, the inoculum was incubated at $37^{\circ} \mathrm{C}$ for 8 hours, and was ready to use as a starter culture.

\section{Preparation of Fermented Whey Dangke}

As much as $250 \mathrm{~mL}$ of filtered whey dangke was put into $1000 \mathrm{~mL}$ of Erlenmeyer tube, and yeast extract (Merck) was added by $4 \%(w / v)$. The medium of whey dangke was pasteurized in water bath for 1 hour at $65^{\circ} \mathrm{C}$. After the medium cooled down, it was inoculated aseptically by Lactobacillus casei bacteria by $4 \%(\mathrm{v} / \mathrm{v})$, and it was incubated at $41^{\circ} \mathrm{C}$ for 96 hours. Fermented whey dangke was stored in a refrigerator for 24 hours before being dried.

\section{Preparation of Fermented Whey Dangke}

As much as $250 \mathrm{~mL}$ of the filtered fermented whey dangke was taken and added with Tween 80 by $1.5 \%$ (v/v). The mixture was homogenized by blender in medium speed for five minutes, and carrageenan was added in accordance with the treatment and re-homogenized for five minutes. The mixture was poured into a tray with a size of $22,5 \times 22,5 \times 1 \mathrm{~cm}^{3}$, and then it was dried with $0,5 \mathrm{~mm}$ thickness by using oven (GFL 7106) at $70^{\circ} \mathrm{C}$. After drying time had been achieved based on the treatment, the dried sheet of fermented why dangke was grinded by using a medium speed blender for three minutes and for another three minutes in high speed. Rough fermented whey dangke powder was filtered by 80 mesh strainer, and the filtered fermented whey dangke was packed in polyethylene plastics and stored in a refrigerator until the parameter measurement was conducted.

\section{Analysis of Fermented Whey Dangke Quality Yield}

Yield was calculated as a ratio of the material weight before drying to that of the resulting powder expressed in a percentage.

\section{Solubility}

One gram of powder was dissolved in $100 \mathrm{~mL}$ aquades, and the solution was centrifuged for 10 minutes at $1500 \mathrm{rpm}$. As much as $25 \mathrm{~mL}$ supernatant was placed in porcelain cups and dried in an oven at $105^{\circ} \mathrm{C}$ for 5 hours. The dry weight was calculated based on AOAC (1995), and the solubility was calculated as a percentage difference in weights before and after drying.

\section{Proximate Analysis}

The moisture content of the fermented whey dangke powder was measured by Oven method (AOAC, 1995), and the protein content was measured by Kjeldhal method (AOAC, 1995). Meanwhile the lactose content was measured by the Fermentation method (SNI, 1992), and moisture, protein, and lactose contents of fermented whey dangke were measured before and after the drying process.

\section{Statistical Analysis}

This research was conducted experimentally by using a Completely Randomized Design (CRD) Factorial Pattern of two factors repeated three times, and the results were stated as mean values \pm SD (Standard Deviation). The first factor treatment was carrageenan levels of $4 \%$, $6 \%, 8 \%$, and $10 \%$ calculated based on the volume of whey fermentation (w/v). The second factor treatment was drying time i.e. 23, 24, and 25 hours. The data were processed in two-way ANOVA by using SPSS 16.0 program. The average value of the parameters that had different superscripts showed significant differences at the level of $5 \%(\mathrm{P}<0.05)$ and $1 \%(\mathrm{P}<0.01)$ obtained from the Duncan difference test results. 


\section{RESULTS AND DISCUSSION Yield}

Yield is a parameter closely related to the economic value of the product in which the higher the yield, the more efficient the production process. The highest yield obtained in this research was $48.40 \%$ which is higher than the results reported by Mulyani, Yulistiani, and Nopriyanti (2014) for passion fruit juice powder products i.e. $18.28 \%$ using a combination of Dextrin $50 \%$ and Tween $800.15 \%$ as drying aids. This can be related to the lactose components in whey which protect the loss of solid product components during the drying process. Lohiya and Avari (2016) stated that lactose is a protecting material which can be used in drying probiotic suspension. Compared with other kinds of sugar, lactose has high glass transition temperature (Tg), as argued by Jayasundera et al. (2009) that the values of Tg in lactose, maltose, sucrose, glucose, and fructose were $101^{\circ} \mathrm{C}, \quad 87^{\circ} \mathrm{C}, \quad 62^{\circ} \mathrm{C}, \quad 31^{\circ} \mathrm{C}$, and $16^{\circ} \mathrm{C}$ respectively. The level of carrageenan addition had a very significant effect $(\mathrm{P}<0.01)$ on the yield of fermented whey dangke powder, while the drying time and interaction of both had no significant effect. Increased product yield started to be evident at the level of $8 \%$ carrageenan addition, and continued to increase at $10 \%$ (Table 1).

This was caused by an increase in total solids as the level of carrageenan addition increased; hence, besides functioning to accelerate the rate of water evaporation, carrageenan can also be a filler. The results obtained imply that carrageenan can change the surface adhesiveness of materials containing organic acids, or in this case lactic acid in order to facilitate drying and reduce the adhesiveness of the product during the drying process with hot air. Chegini and Ghobadian (2007) stated that drying aids are important in the production of juice powder with high sugar and acid levels as these components have low Tg. Karim et al. (2017) also reported that increased levels of carrageenan combined with sodium carboxymethyl cellulose as a coating agent in producing spray-dried Clinacanthus Nutans leaf extract powder could increase the yield of encapsulated powder.

Table 1. Yield of fermented whey dangke powder at various levels of carrageenan and drying time $(\%)$

\begin{tabular}{cccccc}
\hline \multirow{2}{*}{$\begin{array}{c}\text { Drying time } \\
\text { (Hours) }\end{array}$} & 4 & 6 & 8 & 10 & \multirow{2}{*}{ Average } \\
\cline { 2 - 5 } & $36,55 \pm 3,32$ & $36,75 \pm 6,15$ & $42,75 \pm 0,64$ & $48,05 \pm 2,19$ & $41,03 \pm 5,80$ \\
23 & $33,15 \pm 3,46$ & $38,80 \pm 2,12$ & $43,05 \pm 1,63$ & $49,20 \pm 2,12$ & $41,05 \pm 6,54$ \\
24 & $33,20 \pm 3,11$ & $35,25 \pm 6,15$ & $43,95 \pm 1,48$ & $48,40 \pm 1,27$ & $40,20 \pm 7,18$ \\
\hline 25 & $34,30 \pm 3,10^{\text {a }}$ & $36,93 \pm 4,31^{\text {a }}$ & $43,25 \pm 1,17^{\mathrm{b}}$ & $48,55 \pm 1,57^{\mathrm{c}}$ & \\
\hline Average & & & \multicolumn{4}{c}{ Levels of carrageenan $(\%)$} & \\
\hline
\end{tabular}

Note: ${ }^{\mathrm{a}-\mathrm{c}}$ Different letter in the same row indicates significantly different (Duncan test, $\mathrm{P}<0.01$ )

\section{Moisture Content}

Moisture content is an indicator of drying adequacy in a powdered product and can determine the shelf-life, especially on product damage due to microbial growth. The level of carrageenan addition had a very significant effect $(\mathrm{P}<0.01)$ on the water content of the fermented whey dangke powder, while the drying time and interaction of both had no significant effect
(Table 2). The results showed that increasing the level of carrageenan up to $8 \%$ could reduce the moisture content of powdered whey, whereas if the level of carrageenan was increased up to $10 \%$, the moisture content was relatively stagnant. The decrease in product moisture content and the increase of carrageenan level increases were caused by the carrageenan's ability to increase the total solids and reduce 
the moisture content of the ingredients. The increase in total solids resulted in a repulsive force between negative charges along the carrageenan polymer chain; i.e. the sulfate group causing the molecular chains to stiffen, and the solution to thicken (Santoso et al., 2013). The relatively constant moisture content value of fermented whey dangke at $10 \%$ carrageenan level was occurred probably because the moisture content of the product had reached constant values. Various rules specify that the moisture content of powdered products must be below 5\% to maintain product stability during storage. The results indicated that the addition of $8 \%$ carrageenan level could produce a product with water content of $4.57 \%$.

Table 2. Moisture content of fermented whey dangke powder at various levels of carrageenan and drying time $(\%)$

\begin{tabular}{cccccc}
\hline $\begin{array}{c}\text { Drying time } \\
\text { (Hours) }\end{array}$ & 4 & 6 & 8 & 10 & \multirow{2}{*}{ Average } \\
\cline { 2 - 5 } & $9,07 \pm 1,22$ & $7,58 \pm 2,49$ & $4,51 \pm 0,78$ & $3,74 \pm 1,69$ & $6,22 \pm 2,65$ \\
23 & $6,99 \pm 2,34$ & $4,58 \pm 1,97$ & $4,63 \pm 1,46$ & $5,09 \pm 0,13$ & $5,32 \pm 1,66$ \\
24 & $7,60 \pm 2,74$ & $6,76 \pm 0,31$ & $4,59 \pm 2,01$ & $2,30 \pm 0,90$ & $5,31 \pm 2,57$ \\
\hline Average & $7,89 \pm 1,95^{\mathrm{a}}$ & $6,31 \pm 1,99^{\mathrm{ab}}$ & $4,57 \pm 1,17^{\mathrm{bc}}$ & $3,71 \pm 1,51^{\mathrm{c}}$ & \\
\hline
\end{tabular}

Note: ${ }^{\mathrm{a}-c}$ Different letter in the same row indicates significantly different (Duncan test, $\mathrm{P}<0.01$ )

The average moisture content value of fermented whey dangke powder produced in this research was $5.62 \%$. This value is lower compared with the results reported by Pratama et al. (2017) i.e. 6.44-8.04\% in yogurt powder, which also utilized carrageenan as drying aids. This is probably due to the use of higher drying temperatures so that the heat transfer between material and air is greater. Sulaksono et al. (2013) stated that the moisture content of dried yogurt powder with $20 \%$ maltodextrin level and at $52^{\circ} \mathrm{C}$ was $10.3 \%$. This shows that the use of carrageenan as a drying aid of fermented whey is more effective than that of maltodextrin. Similarly, preliminary research has shown that the use of maltodextrin by $20 \%$ has not been able to produce dried fermented whey.

In addition to the role of thickener, carrageenan and maltodextrin can also function as a water binder, thereby reducing the availability of free water in products that can complicate the process of water evaporation during heating. Carrageenan may have lower water-binding ability than maltodextrin. The lower ability of the carrageenan to bind water causes the hydrogen bonding to water breaks and releases more water from the material, which is then evaporated during the drying process.

An increase in drying time from 23 to 25 hours tended to produce whey powder with a slightly decreased moisture content, although it was not statistically and significantly different. This might happend because an increase in drying time would increase the duration of heat transfer between the material and the medium. An increase in drying time after reaching 23 hours was no longer effective in reducing the moisture content of the ingredients. This was likely due to the fact that most of the water left in the material was bound making it difficult to evaporate.

\section{Solubility}

Solubility is expressed as the percentage of powder that is completely soluble in water. The results showed that the level of carrageenan addition, drying time and interaction of both did not significantly affect the solubility of fermented whey dangke powder. Table 3 shows that the level of product solubility tended to increase as the levels of carrageenan and drying time 
increase. This could be attributed to the moisture content of whey dangke powder which decreased as the levels of carrageenan and drying time increased. Materials with low moisture content have more pores for water absorption, so that the materials will be more easily dispersed in water. Quek, Chok, and Swedlund (2007) state that solubility is negatively correlated with powder moisture content in which the lower the powder moisture content, the higher the solubility level. Materials with high moisture content have large particles causing each other to be adhesive making it difficult to spread in water (Straatsma et al., 1999).

Table 3. Solubility of fermented whey dangke powder at various levels of carrageenan and drying time $(\%)$

\begin{tabular}{cccccc}
\hline \multirow{2}{*}{$\begin{array}{c}\text { Drying time } \\
\text { (Hours) }\end{array}$} & \multicolumn{4}{c}{ Levels of carrageenan $(\%)$} & \multirow{2}{*}{ Average } \\
\cline { 2 - 5 } & 4 & 6 & 8 & 10 & \\
\hline 23 & $96,00 \pm 0,00$ & $98,00 \pm 0,00$ & $96,00 \pm 0,00$ & $98,00 \pm 0,00$ & $97,00 \pm 1,07$ \\
24 & $96,00 \pm 0,00$ & $94,00 \pm 0,00$ & $98,00 \pm 2,83$ & $97,00 \pm 4,24$ & $96,25 \pm 2,49$ \\
25 & $98,00 \pm 0,00$ & $96,00 \pm 2,82$ & $99,00 \pm 1,41$ & $98,00 \pm 2,83$ & $97,75 \pm 1,98$ \\
\hline Average & $96,67 \pm 1,03$ & $96,00 \pm 2,19$ & $97,67 \pm 1,97$ & $97,67 \pm 2,34$ & \\
\hline
\end{tabular}

The obtained solubility level ranged from $96.0 \%$ to $98.0 \%$. This value is higher than that of pomegranate juice powder of $92 \%$ by using maltodextrin, or $8 \%$ Arabic gum as a drying aid (Yousefi, EmamDjomeh, and Mousavi, 2011). The higher solubility level of fermented whey dangke powder was probably due to the lactose sugar helping to absorb water so that the powder dissolved more easily. Similar notion was reported by Agustini (2018) in mango powder with $20 \%$ sucrose sugar as drying aids resulted in a solubility index from $97.73 \%$ to $98.90 \%$.

\section{Protein Content}

Protein content becomes a consideration on whether fermented whey dangke powder has the potential to be used as a nutritional enhancing additive for human food products. The level of carrageenan addition had a significant effect $(\mathrm{P}<0.05)$ on the content of fermented whey protein powder while the drying time and the interaction of both did not have a significant effect. Table 4 shows that the addition of carrageenan at $8 \%$ level significantly reduced the protein content of fermented whey dangke powder compared with at $4 \%$ level. Meanwhile, if the carrageenan level is increased by $10 \%$, the protein content does not change. As the carrageenan level increases, a decrease in protein content will increase the total carbohydrate of powder which has an effect of decreasing the protein content of the product.

A decrease in protein content as the drying aid level increases has also been reported by several researchers. Patil, Chauhan, and Singh (2014) stated that an increase in maltodextrin level of $7 \%$ to $12 \%$ in drying guavas would reduce the protein content of the product, from $4 \%$ to $3 \%$. One cause of reduced protein content in powdered products is the maillard reaction process between the protein amine group and the reduced sugar carbonyl group causing lysine to degrade (Damodaran, 1996).

The average protein content of fermented whey dangke powder was $12.04 \%$, indicating an increase compared with the liquid product, which was $2.34 \%$. The same thing was reported by Hardy and Jideani (2018) stating that the protein content of Bogor soy milk flour is higher than that of Bogor soy milk i.e. $0.9 \%$ to $7.6 \%$. The increase was due to the liquid form of the product in which the moisture content was high resulting in lower 
nutritional value. Shretsha et al. (2007) explained that the rapid reduction of moisture content in a spray-dried milk solution resulted in various components of milk (fat, protein, minerals) being concentrated.

This was caused by the migration of milk components to the surface replacing the water phase, and this explained the increased levels of protein in powdered milk products. Increased drying time from 24 to 25 hours tendsed to produce whey powder with a constant protein content. This shows that the level of drying aids has more influence on the protein content of the product than on the drying time factor if the product moisture content has reached an equilibrium level. Heat treatment can cause protein destruction of food products because heat damages hydrogen bonds and non-polar hydrophobic bonds. High temperatures can increase kinetic energy, so that the movement or vibration of protein molecules is faster and will damage the bonds of molecules, and milk proteins will undergo denaturation and coagulation during the drying process (Damasceno et al., 2008).

Table 4. Protein content of fermented why dangke powder at various levels of carrageenan and drying time $(\%)$

\begin{tabular}{|c|c|c|c|c|c|}
\hline \multirow{2}{*}{$\begin{array}{l}\text { Drying time } \\
\text { (Hours) }\end{array}$} & \multicolumn{4}{|c|}{ Levels of carrageenan (\%) } & \multirow{2}{*}{ Average } \\
\hline & 4 & 6 & 8 & 10 & \\
\hline 23 & $13,75 \pm 2,85$ & $13,12 \pm 3,34$ & $10,82 \pm 0,97$ & $9,70 \pm 0,35$ & $11,84 \pm 2,45$ \\
\hline 24 & $13,92 \pm 1,50$ & $12,84 \pm 2,18$ & $11,20 \pm 1,08$ & $10,54 \pm 1,85$ & $12,12 \pm 1,92$ \\
\hline 25 & $13,58 \pm 1,74$ & $12,78 \pm 2,00$ & $11,52 \pm 2,18$ & $10,71 \pm 1,37$ & $12,15 \pm 1,83$ \\
\hline Average & $13,75 \pm 1,64^{\mathrm{a}}$ & $12,91 \pm 2,00^{\mathrm{ab}}$ & $11,18 \pm 1,21^{\mathrm{bc}}$ & $10,32 \pm 1,15^{\mathrm{c}}$ & \\
\hline
\end{tabular}

Note: ${ }^{\mathrm{a}-\mathrm{c}}$ Different letter in the same row indicates significantly different (Duncan test, $\mathrm{P}<0.05$ )

Table 5. The lactose content of fermented whey dangke powder at various levels of carrageenan and drying time $(\%)$

\begin{tabular}{cccccc}
\hline $\begin{array}{c}\text { Drying time } \\
\text { (Hours) }\end{array}$ & \multicolumn{4}{c}{ Levels of carrageenan $(\%)$} & \multirow{2}{*}{ Average } \\
\cline { 2 - 5 } & 4 & 6 & 8 & 10 & \\
\hline 23 & $15,58 \pm 0,66$ & $14,26 \pm 0,40$ & $11,98 \pm 2,69$ & $9,49 \pm 1,72$ & $12,83 \pm 2,77^{\mathrm{a}}$ \\
24 & $13,91 \pm 1,09$ & $11,10 \pm 0,11$ & $9,82 \pm 1,57$ & $7,92 \pm 0,16$ & $10,69 \pm 2,44^{\mathrm{b}}$ \\
25 & $11,30 \pm 1,25$ & $10,66 \pm 1,10$ & $10,49 \pm 1,07$ & $9,03 \pm 0,08$ & $10,37 \pm 1,16^{\mathrm{b}}$ \\
\hline Average & $13,60 \pm 2,09^{\mathrm{a}}$ & $12,00 \pm 1,83^{\mathrm{b}}$ & $10,76 \pm 1,77^{\mathrm{b}}$ & $8,81 \pm 1,06^{\mathrm{c}}$ & \\
\hline
\end{tabular}

Note: ${ }^{\mathrm{a}-\mathrm{c}}$ Different letter in the same row or column indicates significantly different (Duncan test, $\mathrm{P}<0.01)$

\section{Lactose Content}

Lactose is a carbohydrate form of disaccharide found in milk, and it is avoided by some people with lactose intolerance as it can cause digestive disorders. The average lactose content of whey dangke powder obtained was $12.30 \%$ which means there was an increase of $2.35 \%$ in liquid form. This is caused by the concentrated lactose as a result of decreased water content of the product. The results in Table 5 show that the increasing level of carrageenan addition and drying time significantly $\quad(\mathrm{P}<0.01)$ decreased the lactose content of fermented whey powder, while the interaction of both had no significant effect. Decreased lactose content started at $6 \%$ carrageenan level, and continued at $10 \%$ level. A decrease in sugar content of the product with an increase in drying aid level was also reported by Patil et al. (2014) in which maltodextrin was used in producing guava flour. Similar to protein, 
the decrease in lactose content of fermented whey powder may be due to the decrease in water content as the carrageenan level increases.

The lactose powder content of fermented whey dangke at 23 hour drying time was significantly higher $(\mathrm{P}<0.01)$ compared to 24 and 25 hour drying time, whereas the lactose powder contents between 24 and 25 hours were the same (Table 5). This means that lactose loss was greater as the drying time of whey increased. This was probably because lactose was in the evaporating water during the drying process. Lactose is a disaccharide that dissolves easily in water at hot temperature.

\section{CONCLUSION}

Fermented whey dangke powder can be produced with a drying oven at $70^{\circ} \mathrm{C}$ with carrageenan as the supporting material. The level of carrageenan and drying time to produce optimum quality of fermented whey dangke powder is $8 \%$ and at 24 hours when observed from the physicochemical characteristics of the product.

\section{ACKNOWLEDGMENT}

We would like to express our gratitude to Kemenristekdikti as the funder of this research through the Decentralization of Higher Education Applied Research Grant in 2018.

\section{REFFERENCES}

Agustini, S. (2018). The characterization of mango ( Mangifera indica L ) powder of various drying temperature. Journal of Physics: Conference Series, 1095, 012035. https://doi.org/ 10.1088/1742-6596/1095/1/012035

Association of Official Agricultural Chemists. (1995). Official Methods of Analysis. Washington DC: AOAC.

Catur Sulaksono, A., Kumalaningsih, S., and Santoso, I. (2013). Production and processing of yoghurt powder using foam-mat drying. Food and Public Health, 3(5), 235-239. https:// doi.org/10.5923/j.fph.20130305.01

Chegini, G. R., and Ghobadian, B. (2007). Spray dryer parameters for fruit juice drying. World Journal of A gricultural Sciences, 3(2), 230-236.

Damasceno, L. F., Fernandes, F. A. N., Magalhães, M. M. A., and Brito, E. S. (2008). Evaluation and optimization of non enzymatic browning of "cajuina" during thermal treatment. Brazilian Journal of Chemical Engineering, 25(2), 313-320. https://doi.org/10.1590/S0 104-66322008000200010

Damodaran, S. (2017). Amino acids, peptides, and proteins. In Fennema's Food Chemistry (pp. 235-356). CRC Press. https://doi.org/10.1201/978131 5372914

Dinas Peternakan dan Perikanan. (2012). Laporan Data Populasi Ternak per Kecamatan Kabupaten Enrekang 2012. Dinas Peternakan dan Perikanan, kabupaten Enrekang.

Domingues, L., Dantas, M. M., Lima, N., and Teixeira, J. A. (1999). Continuous ethanol fermentation of lactose by a recombinant flocculating Saccharomyces cerevisiae strain. Biotechnology and Bioengineering, 64(6), 692-697. https:// doi.org/10.1002/(SICI)1097-0290(19990 920)64:6<692::AID-BIT8>3.0.CO;2-J

Fernandes, M. R. V., Dias, A. L. T., Carvalho, R. R., Souza, C. R. F., and Oliveira, W. P. (2014). Antioxidant and antimicrobial activities of Psidium guajava L. spray dried extracts. Industrial Crops and Products, 60, 39-44. https://doi.org/ 10.1016/j.indcrop.2014.05.049

Hardy, Z., and Jideani, V. A. (2018). Effect of spray drying compartment and maltodextrin concentration on the functional, physical, thermal, and nutritional characteristics of Bambara groundnut milk powder. Journal of Food Processing and Preservation, 
42(2), e13491. https://doi.org/10.111 1/jfpp.13491

Jayasundera, M., Adhikari, B., Aldred, P., and Ghandi, A. (2009). Surface modification of spray dried food and emulsion powders with surface-active proteins: A review. Journal of Food Engineering, 93(3), 266-277. https://doi. org/10.1016/j.jfoodeng.2009.01.036

Jittanit, W., Niti-Att, D., and Techanuntachaikul, O. (2010). Study of spray drying of pineapple juice using maltodextrin as an adjunct. Chiang Mai Journal of Science, 37(3), 498-506.

Karim, N. A., Muhamad, I. I., Pae, N., and Aziz, R. A. (2017). Effect of spray drying conditions on the antioxidant and physicochemical properties of clinacanthus nutans leaves extracts. Chemical Engineering Transactions, 56, 961-966. https://doi.org/10.3303/ CET1756161

Kha, T. C., Nguyen, M. H., and Roach, P. D. (2010). Effects of spray drying conditions on the physicochemical and antioxidant properties of the Gac (Momordica cochinchinensis) fruit aril powder. Journal of Food Engineering, 98(3), 385-392. https://doi. org/10.1016/j.jfoodeng.2010.01.016

Krishnaiah, D., Sarbatly, R., and Nithyanandam, R. (2012). Microencapsulation of Morinda citrifolia L. extract by spray-drying. Chemical Engineering Research and Design, 90(5), 622-632. https://doi. org/10.1016/j.cherd.2011.09.003

Lohiya, G. K., and Avari, J. G. (2016). Optimization of feed composition for spray drying of probiotics. Journal of Innovations in Pharmaceuticals and Biological Sciences, 3(1), 154-161.

Mulyani, T., Yulistiani, R., and Nopriyanti, M. (2014). Pembuatan bubuk sari buah markisa dengan metode "FoamMat Drying." Jurnal REKAPANGAN, 8(1), 22-38.
Patil, V., Chauhan, A. K., and Singh, S. P. (2014). Influence of spray drying technology on the physical and nutritional properties of guava powder. International Journal of Current Microbiology and Applied Sciences, 3(9), 1224-1237.

Pratama, Y., Abduh, S. B. M., Legowo, A. M., Pramono, Y. B., and Albaarri, A. N. (2017). Optimum carrageenan concentration improved the physical properties of cabinet-dried yoghurt powder. In Paper presented at The 2nd International Symposium on Food and Agro-biodiversity (ISFA). Semarang. https://doi.org/doi.org/10. 1088/1755-1315/102/1

Quek, S. Y., Chok, N. K., and Swedlund, P. (2007). The physicochemical properties of spray-dried watermelon powders. Chemical Engineering and Processing: Process Intensification, 46(5), 386-392. https://doi.org/10.10 16/j.cep.2006.06.020

Santoso, B., Herpandi, H., Pitayati, P., and Pambayun, R. (2013). Pemanfaatan karaginan dan gum arabic sebagai edible film berbasis hidrokoloid. Jurnal Agritech Fakultas Teknologi Pertanian UGM, 33(2). https://doi. org/10.22146/agritech.9802

Shrestha, A. K., Howes, T., Adhikari, B. P., and Bhandari, B. R. (2007). Water sorption and glass transition properties of spray dried lactose hydrolysed skim milk powder. $L W T$ Food Science and Technology, 40(9), 1593-1600. https://doi.org/10.1016/j. lwt.2006.11.003

Standar Nasional Indonesia. (1992). Yogurt. Jakarta: Badan Standarisasi Nasional.

Straatsma, J., Van Houwelingen, G., Steenbergen, A. E., and De Jong, P. (1999). Spray drying of food products: 2 . Prediction of insolubility index. Journal of Food Engineering, 42(2), 73-77. https://doi.org/10.1016 /S0260-8774(99)00108-9 
Yousefi, S., Emam-Djomeh, Z., and Mousavi, S. M. (2011). Effect of carrier type and spray drying on the physicochemical properties of powdered and reconstituted pomegranate juice (Punica Granatum L.). Journal of Food Science and Technology, 48(6), 677-684. https:// doi.org/10.1007/s13197-010-0195-X 